\title{
Use Properties of the AlSi9Mg Alloy With Exothermical Modifier
}

Assoc. Prof. Tomasz Lipiński Dr.Sc.

University of Warmia and Mazury in Olsztyn, The Faculty of Technical Sciences Department of Materials and Machines Technology, St: Oczapowskiego 11,10-957 Olsztyn, Poland. tomasz.lipinski@uwm.edu.pl

The improvement in mechanical properties generally has been attributed of the morphology and size of the $\alpha$ - and $\beta$ phase. Chemical elements and compounds, both added to the alloy and formed as a result of exothermic reactions, "pass" into the alloy, changing the course of its crystallization. Selection of the mixture components allows - to a degree - to decide about the starting moment of crystallization and change the range of solidification of alloy or its individual phases. Control over crystallization by acceleration or deceleration of the equilibrium process enables to affect the alloy structure. Another advantage may be addition of the desired components. Properly selected, they can influence crystallization and after alloy solidification - play an important role in its further use. This work present results modification AISi9Mg alloy with modifier contained Na, F and Cl. It modifier was has taken down was with components: $\mathrm{NaCl}, \mathrm{Na}_{3} \mathrm{AlF}_{6} \mathrm{i} \mathrm{NaF}$. The influence of modifier in reference to pulp of worked alloy on elongations, Brinell hardness, impact strength was introduced in graphic method. The analysis modification process of eutectic alloy AlSi9Mg with compound modifier showed the modifying influence on studied proprieties of AISi9Mg alloy.

Keywords: Al-Si alloy, silumin, mechanical properties, metallothermy

\section{References}

[1] Ахназарова С.Л., В.В. Кафаров (1978). Оптимализация эксперимента в химии и химической технологии. Издательство Высшая школа. Москва.

[2] Borkowski S. (1999). Sterowanie jakością tworzyw odlewniczych na przykładzie żeliwa. WNT Warszawa.

[3] Borkowski S., T. Lipiński (1997). Wpływ dodatków egzotermicznych na właściwości mechaniczne odlewniczych stopów aluminium. Acta Academia Agriculturae ac Technicae Olstenensis. Mechanica 29, pp. 50-58.

[4] Bydałek, A. (1994). Powierzchniowe oddziaływanie azotu w procesie żużlowej rafinacji miedzi. II Konf. Zjawiska powierzchniowe w procesach odlewniczych. Poznań-Kołobrzeg pp. 53-58.

[5] Flood S.C., J.D. Hunt (1981). Modification of Al-Si eutectic alloys with Na. Metal Science 15, pp. 287.

[6] Lipiński T. and A. Wach (2008). Quality management silumin Al-12\%Si alloy by mixture on base Cl, Na and F. Quality and production management in practice. Charper 12, pp. 75-80. Publishing and Press Association of Universities Russia. Sain-Petersburg.

[7] Lipiński T. (2010). Tensile Strength of the Al-9\%Si Alloy Modified with Na, F and Cl Compounds. Archives of Foundry Engineering 10, pp. 89-92.

[8] Lipiński T., M Bramowicz., P. Szabracki, P. Mikołajczyk and M. Cudakiewicz (2010) Abrasive Wear of the AlSi12Mg With Al-Si Alloy for Casting Machine Parts. Technical Sciences 13, pp 212-220.

[9] Nova I., J.Exner, Z.Hosek and I.Novakova (2004). Crystallization of Al-Si alloys in the course of high pressure diecasting. Archives of foundry Vol. 4, Nr 14.

[10] Romankiewicz R., F. Romankiewicz (2009). Influence of modification on the structure and morphology of fractures of silumin AlSi6Cu4. Archives of Foundry Engineering 3/2, pp. 13-16. 